\title{
Separation of endo-polygalacturonase using aqueous two-phase partitioning
}

\author{
You-Ting Wu, Martinha Pereira, Armando Venâncio, José Teixeira* \\ Centro de Engenharia Biológica-IBQF, Universidade do Minho, Braga 4710-057, Portugal
}

Received 28 December 2000; received in revised form 24 July 2001; accepted 24 July 2001

\begin{abstract}
The partitioning of endo-polygalacturonase (endo-PG) in polyethylene glycol (PEG)-polyvinyl alcohol (PVA10 000) and PEG-hydroxypropyl starch (Reppal PES100) aqueous two-phase systems was studied, and revealed the possibility of using aqueous two-phase extraction to purify and concentrate endo-PG from its clarified fermentation broth. For the PEG8000PVA10 000 system, endo-PG presented in the fermentation broth (at concentration that is more than $40 \%$ of total protein) mainly dominates in the top phase with a partitioning coefficient of 6 , while total protein concentrates in the bottom phase. A separation scheme consisting of two consecutive aqueous two-phase extraction steps was proposed: a first extraction in polyethylene glycol (PEG8000)-polyvinyl alcohol system, followed by a second extraction in PEG8000- $\left(\mathrm{NH}_{4}\right)_{2} \mathrm{SO}_{4}$ system. This allowed the separation of endo-PG from polymer and the recycling of PEG polymer, since endo-PG was very strongly partitioned into the bottom phase of the PEG8000- $\left(\mathrm{NH}_{4}\right)_{2} \mathrm{SO}_{4}$ system. Laboratory-scale experiments were performed to test the efficiency of this scheme. It was found that enzyme recovery was up to $91 \%$ with a total purification factor of about 1.9 and a concentration factor of more than 5. About $90 \%$ of the total PEG added into the systems can be recovered, and no reduction was obtained in the purification factor using recycled PEG. (C) 2001 Elsevier Science B.V. All rights reserved.
\end{abstract}

Keywords: Partitioning; Aqueous two-phase systems; Enzymes; Endo-polygalacturonase

\section{Introduction}

Endo-polygalacturonase-E.C. 3.2.1.15 (endo-PG) production from Kluyveromyces marxianus fermentation has attracted interest and has been widely studied recently [1-3]. Until now, endo-PG has been obtained from Aspergillus niger fermentations. This fungus secretes a wide range of enzymes and other metabolites, which makes more complex the down-

\footnotetext{
*Corresponding author. Tel.: +351-253-604-406; fax: +351253-678-986.

E-mail address: jateixeira@deb.uminho.pt (J. Teixeira).
}

stream processing [4]. The fact that about $90 \%$ of proteins secreted by $K$. marxianus under anaerobic conditions are polygalacturonases [5,6] makes this microorganism a very attractive system for polygalacturonase production. However, most of the separation methods recently reviewed [4], were developed for characterisation purposes rather than commercial implementation, and usually involve a combination of centrifugation, precipitation, membrane and gel filtrations, ion-exchange and affinity chromatography and/or dialysis. Therefore, it is important to develop a separation process of high enzyme recovery and low capital and operating costs 
to recover endo-PG from the fermentation broth of $K$. marxianus for commercial use.

Aqueous two-phase extraction (ATPE) is an attractive separation method for enzymes and other biological substances [7-9]. The aqueous two-phase systems (ATPS) can provide a gentle and friendly environment to biological materials, and their performance can be controlled and optimized by varying solution conditions. In addition, being a liquid-liquid extraction type operation, these systems can also be readily scaled up. All these features make aqueous two-phase extraction a convenient and potentially useful method for the separation, purification and concentration of biomaterials. Furthermore, a preliminary study [10] has found the possibility of using polyethylene glycol (PEG)-salt ATPS to extract endo-PG with high enzyme recovery up to $95 \%$ and a concentration factor of 5 to 8 . However, the purification factor is not optimal $(<1.3)$.

This study presents the partitioning of endo-PG and total protein from a clarified fermentation broth in PEG-polyvinyl alcohol and PEG-hydroxypropyl starch ATPS with the aim of finding a more suitable system to develop the ATPE process for enzyme recovery and purification.

\section{Materials and methods}

PEG8000 and PEG20 000 were obtained from Promega Corporation (WI, USA), polyvinyl alcohol (PVA10 000, 88\% hydrolysed) was from Scientific Polymer Products (NY, USA) and hydroxypropyl starch (PES100) was from REPPE AB (Sweden). Other chemicals were of analytical reagent grade.

Endo-PG fermentation broth was obtained from the shaking incubation of $K$. marxianus CCT3172 at $30^{\circ} \mathrm{C}$ in the following media $\left(1^{-1}\right): 10 \mathrm{~g}$ glucose, 3.0 $\mathrm{g}\left(\mathrm{NH}_{4}\right)_{2} \mathrm{SO}_{4}, 4.5 \mathrm{~g} \mathrm{KH}_{2} \mathrm{PO}_{4}, 0.25 \mathrm{~g} \mathrm{MgSO}_{4} \cdot 7 \mathrm{H}_{2} \mathrm{O}$, $0.25 \mathrm{~g} \mathrm{CaCl}_{2}$ and $1.0 \mathrm{~g}$ yeast extract. The fermentation broth was clarified by centrifugation before using. Experiments done to characterise the effect of PEG-PVA and PEG-PES ATPS properties on enzyme and total protein partition were done using previously lyophilised clarified fermentation broth. After selection of the most adequate system composition, experiments for endo-PG purification and concentration were done using clarified fermentation broth (without lyophilisation).

All polymer concentrations were calculated as percentage weight/weight $(\% \mathrm{w} / \mathrm{w})$. On both cases (study of the effect of ATPS properties and experiments for purification and concentration) the aqueous two-phase systems were prepared by adding the pure-phase components or recycled PEG polymer solution to the clarified endo-PG fermentation broth or enzyme sample.

In partition experiments, $0.2 \mathrm{ml}$ enzyme sample was added into ATPS to form a $1 \mathrm{~g}$ total solution. After mixing, the solution was centrifuged at 3000 $\mathrm{rpm}$ for $3 \mathrm{~min}$ and put in an air bath at $20^{\circ} \mathrm{C}$ for over $12 \mathrm{~h}$. Samples of top and bottom phases were taken for the assays of enzyme and total protein. The partitioning coefficients of enzyme and total protein, $K_{\mathrm{e}}$ and $K_{\mathrm{p}}$, were defined as the ratio of enzyme activity or protein concentration in the top and bottom phases, respectively.

For the purification and concentration experiments, the PEG-PVA system was prepared using 30\% PVA stock solution and either 50\% PEG stock solution, solid PEG or recycled PEG solution (about $52 \%(\mathrm{w} / \mathrm{w})$ for PEG). These polymer solutions and the clarified fermentation broth were mixed to the required compositions. Depending on the type of PEG used, the fermentation broth consists of 56$64 \%(\mathrm{w} / \mathrm{w})$ of the total system. In the preparation of the PEG- $\left(\mathrm{NH}_{4}\right)_{2} \mathrm{SO}_{4}$ system, solid ammonium sulphate was used, while the PEG was obtained from the recycled PEG and from the top phase of a PEG-PVA system.

The phase diagram is constituted of a binodal curve and tie-lines [7]. The binodal curve represents the border line between one-phase and two-phase regions. The tie-line describes the composition of the two phases in equilibrium. The tie-line length (TLL) is defined as:

$$
\begin{aligned}
& \operatorname{TLL}(\%)= \\
& \sqrt{\left(\% \mathrm{PEG}_{\text {top }}-\% \mathrm{PEG}_{\mathrm{bottom}}\right)^{2}+\left(\% \mathrm{PVA}_{\text {top }}-\% \mathrm{PVA}_{\mathrm{bottom}}\right)^{2}}
\end{aligned}
$$

where $\mathrm{PEG}_{\text {top }}, \mathrm{PEG}_{\text {bottom }}, \mathrm{PVA}_{\text {top }}$ and $\mathrm{PVA}_{\text {bottom }}$ represent percentage weight composition of each phase forming polymer in top and bottom phases.

The phase diagram of PEG8000-PVA10 000 was 
determined by freeze-drying and refractive-index measurements of the phases [7]. Freeze-drying measurement was performed in a lyophilisation device Christ Alpha 2-4 (B. Braun, Germany) and refractive index was measured in a refractometer $3 \mathrm{~T}$ (Atago-Japan). The phase diagram data of PEG20 000-PVA10 000 and PEG8000-PES100 systems were obtained from literature [8] and Reppal ${ }^{\circledR}$ PES 100 specification (REPPE AB Company Sweden), respectively.

The protein concentration was measured with a Coomassie Protein assay reagent (Pierce, USA) [11]. The enzyme activity was determined by measuring the release of reducing groups from polygalacturonic acid using cyanoacetamide reagent [12], and the activity unit $\left(\mathrm{U} \mathrm{ml}^{-1}\right)$ was expressed as $\mu \mathrm{mol}$ galacturonic acid equivalents released per minute per $\mathrm{ml}$ enzyme solution.

Polyacrylamide gel electrophoresis in the presence of sodium dodecyl sulphate (SDS-PAGE) was performed [13]. Acrylamide gels (12\% w/v) were used and calibrated with markers (Amersham Pharmacia Biotech Inc, USA). Samples from fermentation broth and from concentration/purification process were dialysed and then concentrated with PEG20 000. Before loading into gels, samples were mixed in a $1: 1$ ratio $(\mathrm{v} / \mathrm{v})$ with a loading buffer and heated $\left(65^{\circ} \mathrm{C}, 20 \mathrm{~min}\right)$. Electrophoresis was performed at 50 $\mathrm{V}$ current until the bromophenol blue marker ran off the bottom of the gel. Gels were stained with silver solution [14].

\section{Results and discussion}

\subsection{Determination of phase diagram}

Phase diagram data for any aqueous two-phase extraction process are necessary. The phase diagram (tie-lines and binodal) of PEG8000-PVA10 000 system was determined as shown in Fig. 1. In the same figure, the binodal curve for PEG20 000PVA10 000 system was also shown for comparison [8]. PEG8000 has a smaller molecular mass than PEG20 000, which leads to the formation of two phases at higher polymer concentrations. Small amounts of salts, such as $1.0 \%(\mathrm{w} / \mathrm{w})\left(\mathrm{NH}_{4}\right)_{2} \mathrm{SO}_{4}$ or $25 \mathrm{~m} M$ citrate buffer, have little influence on the

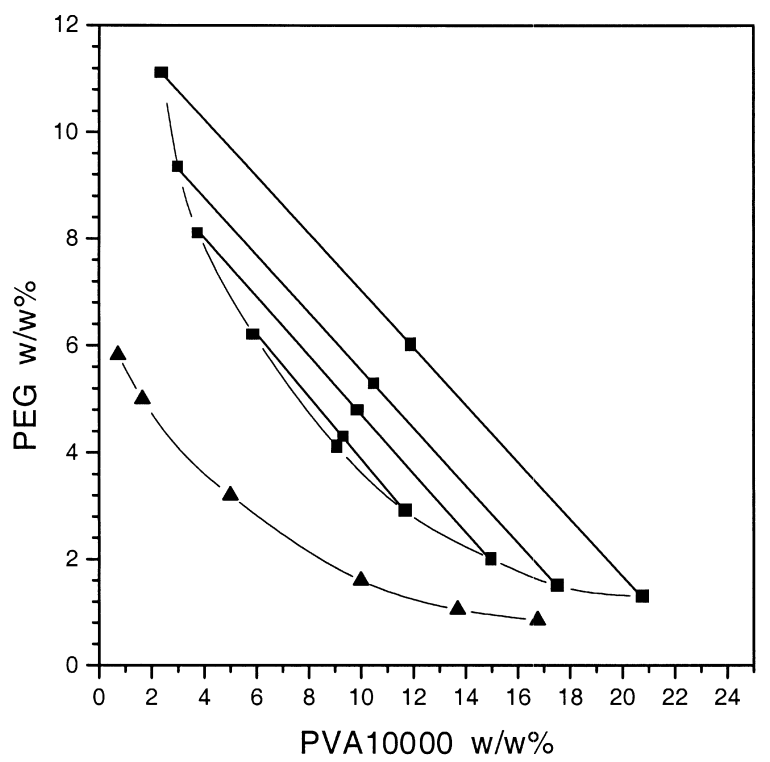

Fig. 1. Phase diagram of PEG-PVA10 000 (88\% hydrolyzed) systems. Binodal and tie-lines (ם-口) for PEG8000 system; binodal ( $\mathbf{\Delta}-\mathbf{\Delta})$ for PEG20 000 system, as in Ref. [8].

tie-lines, but slightly affect the binodal curve near the critical point. This is particularly important when entire fermentation broth is used, as salts are present.

\subsection{Partitioning of endo-PG and total protein}

The partitioning behaviour of endo-PG and total protein from a lyophilised fermentation broth in PEG-PVA10 000 systems and PEG8000-hydroxypropyl starch (PES 100) system was experimentally investigated. For the PEG8000-PVA10 000 and PEG20 000-PVA10 000 systems, as shown in Figs. 2 and 3, endo-PG concentrated in the top phase and total protein mainly in the bottom phase, with the partitioning coefficients ranging from 3.0 to 6.5 and from 0.36 to 0.75 , respectively. While PEG molecular masses have little influence on the partitioning of enzyme and total protein, polymer concentrations affect the enzyme partition significantly. The enzyme partitioning coefficient remains at a minimum value around 3 until 5\%PEG8000-10.4\%PVA ATPS and until 4\%PEG20 000-9\%PVA ATPS. After these ranges, the partitioning coefficient increases with increasing polymer concentrations, and tends to reach its asymptotic value of about 6 . 


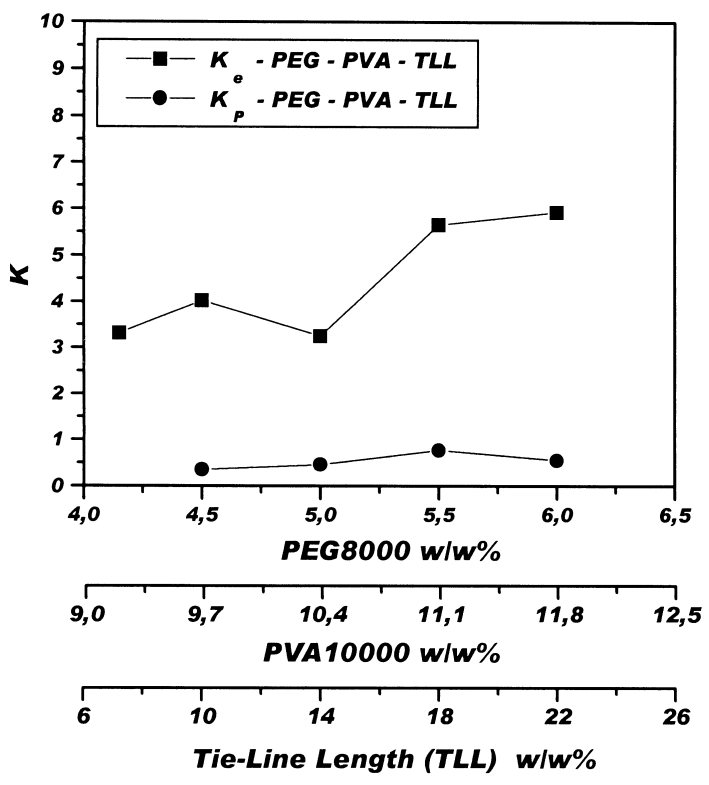

(A)

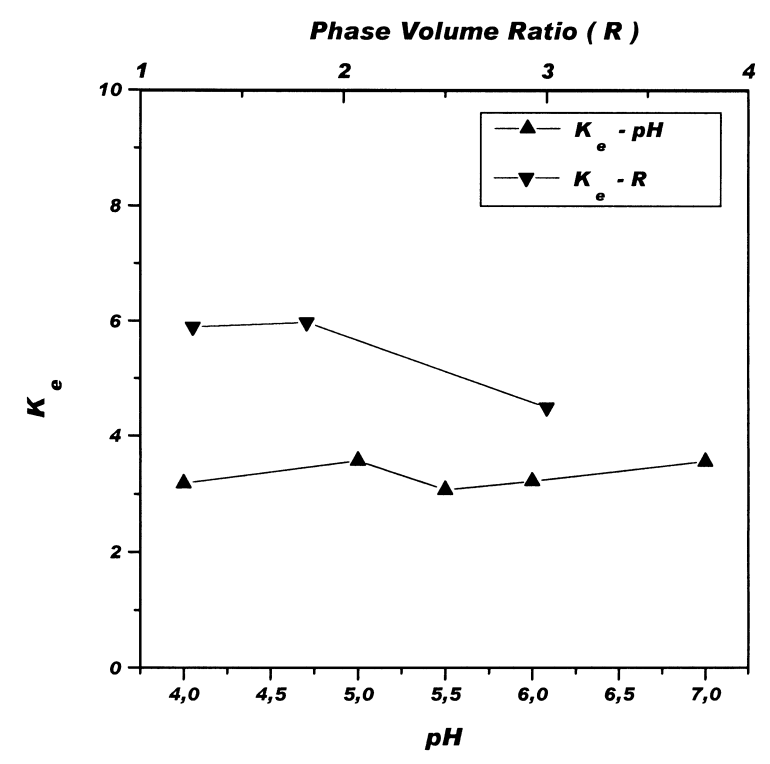

(B)

Fig. 2. Partitioning of endo-PG $\left(K_{\mathrm{e}}\right)$ and total protein $\left(K_{\mathrm{p}}\right)$ in PEG8000-PVA10 000 systems. (A) Effects of polymer concentrations and tie-line lengths. (B) Effects of $\mathrm{pH}\left(K_{\mathrm{e}}-\mathrm{pH}\right)$ and phase volume ratio $\left(K_{\mathrm{e}}-\mathrm{R}\right)$. Enzyme partitioning with respect to $\mathrm{pH}\left(K_{\mathrm{e}}-\mathrm{pH}\right)$ was performed in 4.5\% PEG-9.7\%PVA system using $25 \mathrm{~m} M$ citrate buffer $(\mathrm{pH}<5.5)$ and $25 \mathrm{~m} M$ phosphate buffer $(\mathrm{pH}>5.5)$. Enzyme partitioning with respect to phase volume ratio $\left(K_{\mathrm{e}}-\mathrm{R}\right)$ was done in systems that have a tie line of $20 \mathrm{w} / \mathrm{w} \%$ in length.

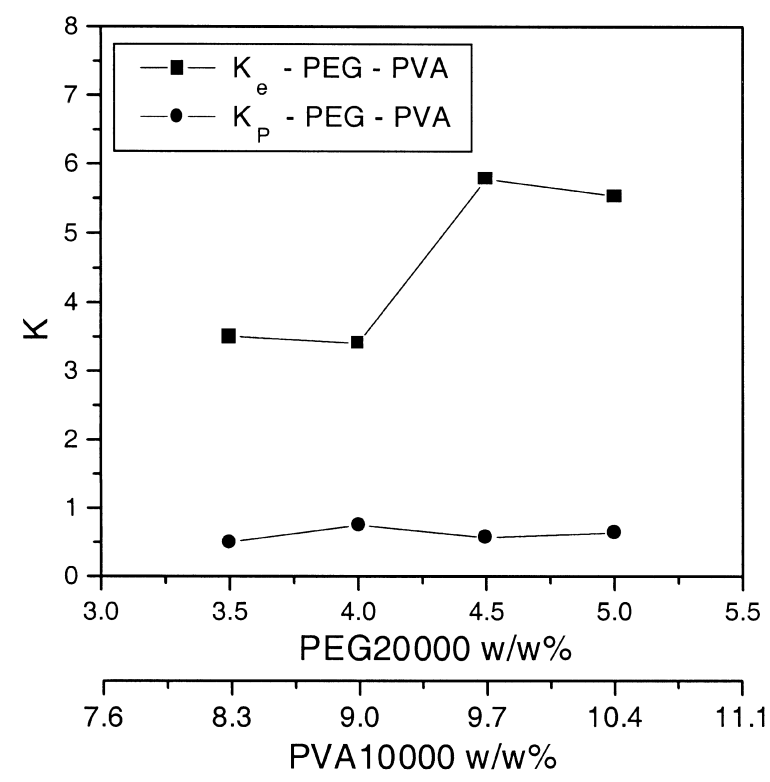

Fig. 3. Partitioning of endo-PG $\left(K_{\mathrm{e}}\right)$ and total protein $\left(K_{\mathrm{p}}\right)$ in PEG20 000-PVA10 000 system.
When the 4.5\%PEG8000-9.7\%PVA system was buffered to have different pHs (using $25 \mathrm{~m} M$ citrate buffer (for $\mathrm{pH}<5.5$ ) and $25 \mathrm{mM}$ phosphate buffer (for $\mathrm{pH}>=5.5)$ ), little change was found in the enzyme partitioning (Fig. 2B), which implies that charges in the enzyme protein have little contribution to the enzyme partition. The phase volume ratio of ATPS (volume ratio of top phase to bottom phase) also has a weak influence on the enzyme partitioning. When keeping the tie-line length of the systems to be the same at about $20 \%(\mathrm{w} / \mathrm{w})$, the partitioning coefficient of enzyme decreases slightly when the phase volume ratio exceeds 2 . The optimised phase volume ratio is about 2 from the requirements for high enzyme recovery and purification factor.

Fig. 4. As for the partitioning behaviour of endoPG and total protein in PEG8000-PES100 ATPS, shown in Fig. 4, both enzyme and total protein tend to be equally partitioning with the coefficients ranging from 0.75 to 0.5 and from 0.95 to 0.80 , respectively. The $\mathrm{pH}$ also changes little the partitioning 


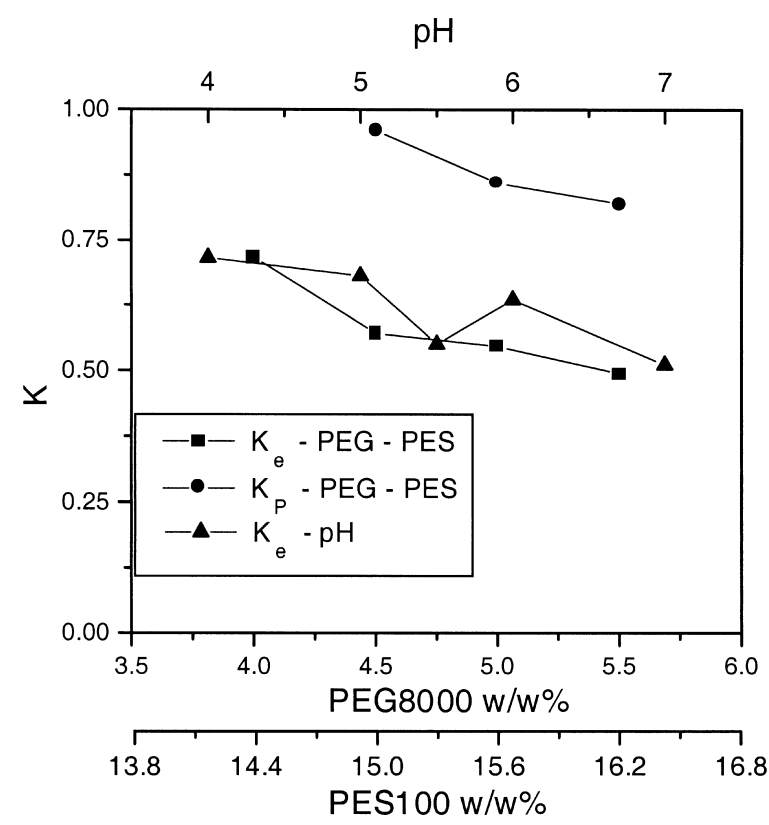

Fig. 4. Partitioning of endo-PG $\left(K_{\mathrm{e}}\right)$ and total protein $\left(K_{\mathrm{p}}\right)$ in PEG8000-PES100 system. Enzyme partitioning with respect to $\mathrm{pH}\left(K_{\mathrm{e}}-\mathrm{pH}\right)$ was performed in $4.5 \%$ PEG-15\%PES system using $25 \mathrm{~m} M$ citrate buffer $(\mathrm{pH}<5.5)$ and $25 \mathrm{~m} M$ phosphate buffer $(\mathrm{pH}>5.5)$. behaviour of enzyme (using the same buffers). It means that the PEG8000-PES100 system has no actual use for this enzyme separation.

The partitioning of enzyme and total protein in PEG8000- $\left(\mathrm{NH}_{4}\right)_{2} \mathrm{SO}_{4}$ had also been studied previously in this laboratory [10], and is briefly summarised. Both endo-PG and total protein strongly oneside concentrate in the bottom phase. Especially, a study showed that the enzyme partitioning coefficient could be very low $\left(\log K_{\mathrm{e}}<=-2.3\right)$ in an optimised PEG8000- $\left(\mathrm{NH}_{4}\right)_{2} \mathrm{SO}_{4}$ system which has a large phase volume ratio (8 to 10 ) and a moderate tie-line length (about 28\% (w/w)). It means that the concentration operation for the endo-PG can be easily realised using PEG8000- $\left(\mathrm{NH}_{4}\right)_{2} \mathrm{SO}_{4}$ ATPS.

\subsection{Separation scheme for the recovery of endo- $P G$}

Based on the previous results, a separation scheme for the recovery of endo-PG from a clarified fermentation broth was developed. This scheme consists of three consecutive extraction steps (Fig. 5): a first extraction for the separation of endo-PG from other proteins; a second step for the concentration of

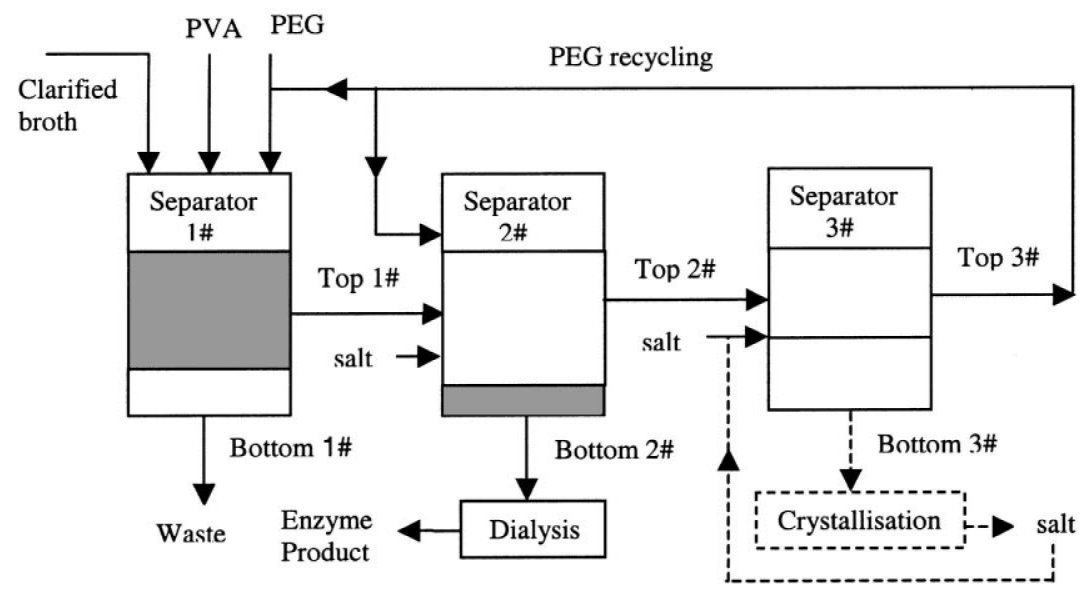

Fig. 5. Schematic view of the proposed separation scheme for endo-PG recovery. The first system was prepared by mixing $6.9 \mathrm{~g}$ of solid PEG, $29 \mathrm{~g}$ of $30 \%$ PVA stock solution and $64.1 \mathrm{~g}$ of fermentation broth. This solution was centrifuged at $3000 \mathrm{rpm}$ during $5 \mathrm{~min}$. After phase separation $67 \mathrm{~g}$ of top phase was collected. To $60 \mathrm{~g}$ of the top phase of PEG-PVA system, $1.35 \mathrm{~g}$ of solid PEG and $0.395 \mathrm{~g}$ were added to prepare the PEG- $\left(\mathrm{NH}_{4}\right)_{2} \mathrm{SO}_{4}$ system. Phase separation was done by centrifugation and the enzyme collected in the bottom phase. To the top phase of this system ammonium sulphate was added (till phase separation occurred). Concentrated top PEG rich phase was then used in the first step of the separation scheme. $\square$ Enzyme-rich phase ----- Needed further study. 
endo-PG and removal of phase forming polymers; and, finally, a third step for the recycling of PEG.

The first extraction was done in 6.9\%PEG80008.7\% PVA system, which has a phase volume ratio of about 2 and a tie-line length of about $20 \%$ (w/w). By using this system, up to $91 \%$ of the endo-PG loaded to this separator could be recovered in the PEG rich top phase (Table 1).

The second extraction step was done in PEG8000$\left(\mathrm{NH}_{4}\right)_{2} \mathrm{SO}_{4}$ system with a phase volume ratio of 8 to 10 and a tie-line length of $28 \%(w / w)$. This system was prepared by adding solid salt to the top phase removed from the first separator and allows the recovery of almost all the endo-PG loaded to the second separator, in a salt rich phase. Additionally to the recovery of the enzyme, there is a removal of most of the PEG and a reduction in the volume of the enzyme solution. After the second extraction step, the yield of endo-PG recovery decreases slightly to $90.8 \%$, with a purification factor of 1.87 and a concentration factor of 5.2. The dialysis becomes an optional operation in case the salts in the enzyme solution should be removed, without any loss in yield.

The third extraction step was designed for the recycling of PEG polymer. This polymer is present in large amounts in the top phase of both ATPS previously described. Small amounts of PEG are lost, since the PEG concentrations in the bottom phases are very low (lower than $1.5 \%(\mathrm{w} / \mathrm{w})$ for PEG-PVA system and lower than $0.3 \%(\mathrm{w} / \mathrm{w})$ for PEG-salt system). So, the top phase of the second extractor could be loaded to a third separator, where PEG polymer could be concentrated, by adding solid ammonium sulphate. A second PEG8000- $\left(\mathrm{NH}_{4}\right)_{2}$ -
$\mathrm{SO}_{4}$ ATPS is formed with a TLL of 58 to $60 \%$. The PEG rich top phase of this system has about $52 \%$ of PEG, $1.5 \%$ of salt and $1.0 \%$ of PVA. The recycled PEG solution provides all the PEG needed in the second separator and most of the PEG used in the first separator. The salt rich bottom phase is about $27 \%$ of salt and is nearly free of polymers and other substances, so most of the ammonium sulphate can be recovered (using crystallization) and re-used in the scheme.

The recycling procedure was done five times without loss in enzyme recovery, in purification factor and in concentration.

SDS-PAGE was performed to analyse the purity of the enzyme collected in the bottom phase of the second step. Also, a sample from the fermentation broth was analysed. The gel obtained is shown in Fig. 6. Comparing the results obtained from both these samples, it was possible to see that the enzyme collected in the bottom phase of the second separator is pure - no bands corresponding to bulk proteins appeared, while in the fermentation broth other proteins with higher molecular masses were present.

\section{Conclusions}

The separation process by aqueous two-phase extraction should favour both concentration and purification. Endo-PG can be concentrated in the top phase of PEG8000-PVA10 000 system with a partition coefficient up to 6 , while the total protein still dominates in the bottom phase. This indicates that enzyme purification can be realized by an extraction in PEG8000-PVA10 000 system. Meanwhile, the

Table 1

Summary of the laboratory-scale enzyme purification experiments using 50\%PEG stock in both steps

\begin{tabular}{|c|c|c|c|c|c|c|}
\hline Purification step & $\begin{array}{l}\text { Volume } \\
(\mathrm{ml})\end{array}$ & $\begin{array}{l}\text { Total } \\
\text { protein } \\
(\mathrm{mg})\end{array}$ & $\begin{array}{l}\text { Protein } \\
\text { yield } \\
(\%)\end{array}$ & $\begin{array}{l}\text { Total } \\
\text { activity } \\
\text { (U) }\end{array}$ & $\begin{array}{l}\text { Enzyme } \\
\text { yield } \\
(\%)\end{array}$ & $\begin{array}{l}\text { Purification } \\
\text { factor }^{\mathrm{a}}\end{array}$ \\
\hline $\begin{array}{l}\text { Broth supernatant } \\
6.9 \% \text { PEG-8.7\%PVA }\end{array}$ & 113.3 & 1.575 & 100 & 261.7 & 100 & \\
\hline $\begin{array}{l}\text { ATPE, top phase }{ }^{\mathrm{a}} \\
25 \% \text { PEG-5.2\% }\left(\mathrm{NH}_{4}\right)_{2} \mathrm{SO}_{4}\end{array}$ & 128.0 & 0.903 & 57.3 & 238.1 & 91.0 & \\
\hline ATPE, bottom phase ${ }^{\mathrm{a}}$ & 21.6 & 0.764 & 48.5 & 237.7 & 90.8 & $1.87(5.2)$ \\
\hline Dialysis & 37.7 & 0.756 & 48.0 & 239.4 & 91.5 & \\
\hline
\end{tabular}

${ }^{\mathrm{a}}$ The data in brackets are concentration factor. 


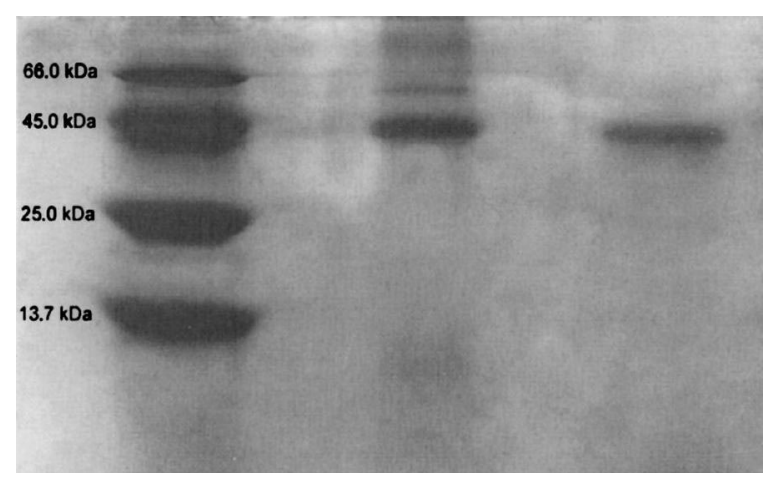

Fig. 6. SDS-PAGE experiments of enzyme samples. Lane 1 is for the standards: bovine albumin serum $(66 \mathrm{kDa})$, ovalbumin $(45$ $\mathrm{kDa})$, chymotrypsinogen $(25 \mathrm{kDa})$, and ribonuclease (13.7 kDa), Lane 2 is for enzyme sample from fermentation broth, and lane 3 is for enzyme sample obtained from aqueous two-phase concentration/purification process.

strong one-side partitioning of endo-PG to the bottom phase of PEG8000- $\left(\mathrm{NH}_{4}\right)_{2} \mathrm{SO}_{4}$ system showed the possibility of enzyme concentration. By integrating these two extractions, a separation scheme was proposed. The experiments showed that up to $91 \%$ of endo-PG could be recovered with a purification factor of 1.9 and a concentration factor of more than 5. About $90 \%$ of total PEG used in the scheme can be recovered at the cost of an extra consumption of $\left(\mathrm{NH}_{4}\right)_{2} \mathrm{SO}_{4}$. The recycled PEG did not represent any loss in enzyme purification and recovery. The extra consumption of $\left(\mathrm{NH}_{4}\right)_{2} \mathrm{SO}_{4}$ can be minimized by crystallizing $\left(\mathrm{NH}_{4}\right)_{2} \mathrm{SO}_{4}$ from the bottom phase. These show that aqueous two-phase extraction can be a powerful method for the downstream processing of endo-PG from its fermentation broth.

\section{Acknowledgements}

You-Ting $\mathrm{Wu}$ and Martinha Pereira were financially supported by the Praxis XXI program of FCT (Fundação para a Ciência e Tecnologia) of Portugal. The work was from project CEC (INCO-DC) with the contract number ERB IC18 CT97 0182.

\section{References}

[1] R. Schwan, A.H. Rose, J. Appl. Bacteriol. 76 (1994) 62.

[2] R. Schwan, R.M. Cooper, A.E. Wheals, Enzyme Microbial Technol. 21 (1997) 234.

[3] M. Pereira, R. Schwan, J. Teixeira, Food Technol. Biotechnol. 37 (4) (1999) 257.

[4] S. Harsa, C.A. Zaror, D.L. Pyle, Process Biochem. 28 (1993) 187.

[5] F.M. Barnby, An Investigation of the Pectinolytic System of Kluyveromyces marxianus, Ph.D. Thesis, University of Reading, 1987.

[6] F.M. Barnby, F.F. Pyle, Enzyme Microbial Technol. 12 (1990) 891.

[7] P.A. Albertsson, Partitioning of Cell Particles and Macromolecules, 3rd edition, Wiley, New York, 1986.

[8] D. Fisher, I.A. Sutherland, Separations Using Aqueous Phase Systems: Applications in Cell Biology and Biotechnology, Plenum, New York, 1989.

[9] M.C. Almeida, A. Venâncio, J.A. Teixeira, M.R. AiresBarros, J. Chromatogr. B 711 (1998) 151.

[10] Y.-T. Wu, M. Pereira, A. Venâncio, J. Teixeira, Bioseparation 9 (2000) 247.

[11] M.M. Bradford, Anal. Biochem. 72 (1976) 248.

[12] S. Honda, Y. Nishimura, M. Takahashi, H. Chiba, K. Kakehi, Anal. Biochem. 119 (1982) 194.

[13] U.K. Laemmli, Nature 227 (1970) 680.

[14] R. Westermeier, Electrophoresis in Practice, VCH, Weinheim, 1993. 